\title{
Chronic exposure to zinc of furnace operators in a brass foundry
}

\author{
EBTISSAM A. HAMDI \\ Department of Industrial Medicine, Faculty of Medicine, Alexandria University, \\ Alexandria, Egypt, U.A.R.
}

\begin{abstract}
Hamdi, A. E. (1969). Brit. J. industr. Med., 26, 126-134. Chronic exposure to zinc of furnace operators in a brass foundry. Twelve furnace operators with chronic exposure to zinc oxide fumes in a brass foundry and 10 normal non-exposed control subjects were studied. Simultaneous determinations of zinc concentrations in the plasma, blood corpuscles, whole blood, and urine were made for each worker and control subject, and in the basal fasting gastric juice and in the gastric secretion half an hour and one hour after gastric stimulation by alcohol in eight workers and seven control subjects.

The workers showed a statistically significant increase of zinc concentration in the blood corpuscles, whole blood, and basal fasting gastric juice compared with the control subjects. Urinary zinc excretion was slightly increased in the exposed workers. The increase in the plasma zinc in the workers was not statistically significant.

Stomach aspiration after alcohol showed a depression of the mean zinc concentration in the gastric secretion after half an hour with a subsequent increase to approximately the fasting level after one hour in both the normal subjects and the workers. Mean zinc concentrations in the gastric juice half an hour and one hour after stomach stimulation were higher in the workers, but the increase was not statistically significant.

It is suggested that the zinc absorbed by these workers is rapidly eliminated from the plasma to be excreted through the gastro-intestinal and urinary tracts; excess zinc is stored in the blood corpuscles. The increased zinc concentration in the gastric secretion of these workers might account, in part, for the high incidence of gastric complaints among them.
\end{abstract}

Acute zinc intoxication has long been recognized in industry. Drinker (1922) described the acute nonfatal illness, metal fume fever or 'brass founder's ague', which occurs on inhalation of zinc oxide fume evolved when zinc is heated to a temperature near its boiling point, as in brass founding. Zinc chloride fumes in high concentration have also been known to be highly toxic and may be fatal (Evans, 1945).

Chronic zinc intoxication, on the other hand, is still a debatable condition in industry. McCord, Friedlander, Brown, and Minster (1926) reported 12 cases of chronic poisoning out of 15 workers in two galvanizing plants where sheet metal was coated with molten zinc. Gastro-intestinal symptoms dominated the clinical picture. Anorexia, nausea, vomiting, epigastric pain, and loss of weight were the most common complaints. Zinc was found in increased amounts in the urine of some cases. However, zinc was not thought to be the only causative agent; other potentially harmful substances, such as hydrogen sulphide and arsenic, were also considered responsible for the poisoning. Batchelor, Fehnel, Thomson, and Drinker (1926) reported raised blood, urinary, and faecal zinc levels in men, engaged for periods of two to 25 years in various processes in the manufacture of zinc oxide and other zinc compounds, without evidence of chronic disease attributable to zinc. They concluded that 
zinc was absorbed and excreted in amounts greater than normal and that relatively large amounts might pass for years through the kidneys and gastrointestinal tract without causing any detectable clinical damage. du Bray (1937) described a case of chronic zinc intoxication in a worker who prepared by hand a solution of zinc chloride used for stabilizing feathers in a pillow factory. Gastro-intestinal disturbances, loss of appetite, loss of weight, bone pains, hypochromic anaemia, and increased zinc excretion in the urine were present. Zinc was assumed to have been absorbed through the skin by direct contact of the hands and forearms with the zinc solution. A fatal case of "chronic pneumoconiosis' was attributed to the inhalation of zinc stearate dust (Noro and Uotila, 1954; Uotila and Noro, 1957).

The present study was designed to investigate a group of industrial workers exposed for some years to the inhalation of zinc oxide fumes in a brass foundry, and to study some aspects of the behaviour of zinc in these workers compared with a group of normal non-exposed control subjects.

\section{Industrial process}

Brass alloys of different compositions were manufactured in the foundry where the study was carried out. The industrial process involved melting copper in a furnace at a temperature of about $1,100^{\circ} \mathrm{C}$; zinc was then added to the molten copper. The amount of copper used varied from $58-85 \%$ by weight of the alloy. The amount of zinc varied from $15-42 \%$. One or more of the following metals lead, tin, aluminium, manganese, arsenic, magnesium, iron, phosphorus, and silicon-were sometimes added in small amounts ranging from $0.01-3 \%$ according to the required specifications of the alloy. After thorough mixing, the molten contents of the furnace were poured into cylindrical moulds. Zincbase alloys were also manufactured in which zinc formed $80 \%$ of the alloy, the remainder being copper, magnesium, and aluminium. Two open furnaces were in operation, each giving an output of four to six pourings every shift. It took from one to two hours to process the alloy, the size of the pouring being 400,500 or 700 kilograms.

Twelve workers were in charge of operating the furnaces. There were three shifts per day; four workers were on duty every shift, two at each furnace. They worked eight hours per day, six days per week, in close proximity to the furnaces, melting and mixing the metals. They were heavily exposed to the zinc oxide fumes evolved when zinc was added to the molten copper in the furnace. Neither an efficient exhaust ventilation system over the furnaces nor proper personal protective equipment for the workers was available in the foundry. These 12 furnace operators made up the group of workers investigated in the present study.

\section{Material and methods}

A detailed occupational history was taken and a complete clinical examination was carried out. Records of each worker's exposure to the zinc oxide fumes during the whole of his employment would have been invaluable, but such information could not be obtained because of inadequate air sampling in the foundry and because of frequent changes in the composition of the brass alloys manufactured.

Ten normal male control subjects of the same age group and the same social and economic status as the exposed workers were also studied. They had never been employed in any industry with exposure to zinc or to other metals.

The workers were investigated on the last day of the working week. Each worker and control subject was instructed in the collection of 24-hour urine samples in an acid-cleaned polyethylene bottle into which urine was passed directly; toluene was used as the preservative. Following a light supper the day before and an overnight fast, the subject came in the morning with a 24-hour urine specimen and was weighed. For zinc determination, a venous blood sample (about $15 \mathrm{ml}$.) was withdrawn into a test tube with dried heparin, using a stainless steel needle and an all-glass syringe. The first portion of blood was allowed to run off into another tube before the sample was taken.

In eight workers and seven control subjects, a polyethylene gastric tube was introduced into the stomach. The fasting gastric juice was aspirated using an all-glass syringe. An alcohol meal (100 ml. of $7 \%$ alcohol in metalfree water) was then introduced into the tube and $10 \mathrm{ml}$. gastric juice vas removed every 15 minutes for two hours. The subject was instructed to expectorate rather than swallow any saliva accumulating in the mouth. The 'free' and 'total' acidity of all the gastric juice samples were measured by titrating against freshly prepared $N / 10$ $\mathrm{NaOH}$, using Topfer's reagent and phenolphthalein as indicators.

The 24-hour urine sample was shaken, its volume measured, and complete urine analysis made. The creatinine content of the urine was determined by Wootton's method (Wootton, 1964) and the 24-hour urinary creatinine excretion was calculated.

Routine liver function tests were performed on all the subjects. Chest radiographs of the workers were available and radiographs of the stomach and duodenum were made on four workers.

Simultaneous determinations of the zinc content of the plasma, blood corpuscles, whole blood, and urine were carried out for each subject. In the subjects given the alcohol meal, the zinc content of fasting gastric juice and of gastric juice collected half an hour and one hour after alcohol intake was also determined at the same time as that of the plasma, blood corpuscles, whole blood, and urine.

\section{Zinc analysis}

A modified zinc analysis technique, based essentially on the methods of Helwig, Hoffer, Thielen, Alcocer, 
Hotelling, and Rogers (1966) and Malmström (1956), was used. Precautions to avoid contamination were taken as outlined by Malmström. 'Polyethylene bottles were used to store the solutions. Twice distilled water in allborosilicate glass was used for preparation of the reagents and in the analytical procedure. For cleaning the polyethylene containers and glassware $2 \mathrm{~N}$ nitric acid was used. The nitric-perchloric-sulphuric acid digestion mixture was prepared by the method of Helwig and his colleagues (1966) and the tartrate solution by the method of Kägi and Vallee (1958). Bromocresol green (0.04\% in $96 \%$ alcohol) was used as the indicator solution. Acetate buffer at $p \mathrm{H} 5.5$ was prepared, as outlined by Malmström (1956). Zinc was extracted by shaking with dithizone solution $\left(0.7 \mathrm{mg}\right.$. \% dithizone in reagent-grade $\left.\mathrm{CC1}_{4}\right)$ prepared fresh every week and stored in a dark borosilicate glass bottle at $4^{\circ} \mathrm{C}$. The standard zinc solution (containing $1 \mu \mathrm{g}$. zinc per $\mathrm{ml}$.) was also prepared fresh every week from a standard stock solution (containing 1,000 $\mu \mathrm{g}$. zinc per $\mathrm{ml}$.) prepared according to the description of Kägi and Vallee (1958).

Briefly, the sample (containing between $0 \cdot 2$ and $2 \mu \mathrm{g}$. zinc) was wet-ashed (Helwig et al., 1966). The tartrate solution was added to the acid-digested sample, which was then titrated with ammonia to a blue colour, a drop of bromocresol solution acting as indicator. Extraction of zinc with dithizone in the presence of the buffer solution followed the same lines as in Malmström's technique. The optical density of the sample (D) was read, with respect to a $\mathrm{CCl}_{4}$ blank, at $620 \mathrm{~m} \mu$ using a Unicam SP 500 spectrophotometer. The optical density of a reagent blank $\left(D_{0}\right)$ and that of a standard $\left(D_{s}\right)$ were determined. The reagent blank and the standard were carried through the entire procedure at the same time as the sample. The results were calculated from the

formula $m=S \times \frac{D_{o}-D}{D_{0}-D_{s}}$, where $m$ and $S$ were the

amounts of zinc in the sample and standard respectively (Malmström, 1956).

The technique of zinc determination was found to be satisfactory. Recovery experiments in the absence and presence of the different biological materials examined were carried out to assess the precision of the method. Duplicate determinations were performed on each sample. A standard plasma was assayed and $1 \mu \mathrm{g}$. zinc recovery was run on this standard with each subject's zinc determination.

Samples for zinc determination were obtained as follows: $5 \mathrm{ml}$. blood was centrifuged in a 10-ml. graduated conical test tube at 3,000 r.p.m. for 30 minutes. The volume of packed blood corpuscles was noted. Packed cell volume (P.C.V.) or haematocrit value was

calculated as $\frac{\text { height of red cell column }(\mathrm{mm} .)}{\text { total height of column }(\mathrm{mm} .)} \times 100$.

The plasma was separated and $\mathbf{1 . 0} \mathrm{ml}$. was analysed for its zinc content. Plasma zinc was calculated in $\mu \mathrm{g}$. $\mathrm{Zn}$ per $100 \mathrm{ml}$. plasma. The blood corpuscles remaining after separation of the plasma were washed twice with zinc-free isotonic saline and centrifuged at 3,000 r.p.m. for 30 minutes each time. They were then haemolysed with twice distilled water and transferred to a 25-ml. volumetric flask and the volume was made up to the mark with water. One millilitre of the resulting homogeneous solution was analysed for its zinc content. Blood corpuscle zinc was calculated in $\mu \mathrm{g} . \mathrm{Zn}$ per $\mathrm{ml}$. blood corpuscles. Whole blood zinc was measured in five subjects. One millilitre of whole blood was haemolysed with $3 \mathrm{ml}$. of twice distilled water and $1.0 \mathrm{ml}$. of the resulting solution was analysed. Whole blood zinc was calculated in $\mu \mathrm{g} . \mathrm{Zn}$ per $100 \mathrm{ml}$. whole blood.

Two millilitres of urine, obtained after thorough shaking of the 24-hour urine specimen, were analysed for zinc content. Urinary zinc was calculated in $\mu \mathrm{g} . \mathrm{Zn}$ per 24 hours; in $\mu \mathrm{g} . \mathrm{Zn}$ per $\mathrm{g}$. creatinine; in $\mu \mathrm{g} . \mathrm{Zn}$ per litre; and in $\mu \mathrm{g} . Z$ nper litre corrected to specific gravity 1.024 .

Two millilitres of the gastric juice, aspirated through the polyethylene gastric tube, were analysed for their zinc content. The zinc content of the gastric juice was calculated in $\mu \mathrm{g} . \mathrm{Zn}$ per $100 \mathrm{ml}$. gastric juice.

The $t$ test was applied to determine the statistical significance of the difference in the mean values between the exposed workers and the non-exposed control subjects.

\section{Results}

There was no statistically significant difference between the mean age of the exposed workers and that of the 10 non-exposed control subjects (Table 1). The mean duration of exposure to zinc oxide fumes of the workers was $11 \pm 5$ years.

Clinical examination showed that none of the workers had a bilharzial liver or spleen. None had any liver disease either clinically or revealed by routine laboratory tests. None had post-alcoholic cirrhosis, in which marked abnormalities of zinc metabolism have been reported (Vallee, Wacker, Bartholomay, and Hoch, 1959). No worker showed signs or symptoms of the syndrome of iron deficiency anaemia, hepatosplenomegaly, dwarfism and hypogonadism, described among Egyptians by Prasad, Miale, Farid, Sandstead, and Schulert (1963a), and Prasad, Sandstead, Schulert, and El Rooby (1963b), in which they found reduced plasma and red cell zinc levels and raised urinary zinc excretion per gram creatinine.

Urine analysis revealed no abnormality except for mild glucosuria in worker no. 5, who was an old hypertensive diabetic patient under medical control. No pathological changes in the stomach or duodenum were detected in any of the four workers (nos. $4,6,11$, and 12) radiographed. Chest radiographs of the workers revealed no nodulation or tuberculous lesion. Worker no. 4 had bronchial asthma and worker no. 9 had mitral stenosis.

\section{Zinc levels in plasma, blood corpuscles, whole blood,} and urine

Table 1 shows the zinc levels in the group of workers exposed to zinc and in the non-exposed control group. The zinc content of whole blood was calculated from the plasma and corpuscle zinc values using the haematocrit. Analysis of whole blood for its 
TABLE 1

Zinc in Plasma, Blood Corpuscles, Whole Blood, and Urine of 12 Brass Foundry Workers with Chronic Exposure to Zinc and 10 Normal Non-exposed Control SubJects

\begin{tabular}{|c|c|c|c|c|c|c|c|c|}
\hline & & $\begin{array}{l}\text { Age } \\
\text { (yrs) }\end{array}$ & $\begin{array}{c}\text { Expo- } \\
\text { sure }(y r s)\end{array}$ & $\begin{array}{c}\text { Plasma Zn } \\
(\mu g . / 100 \mathrm{ml} .)\end{array}$ & $\begin{array}{c}\text { Blood } \\
\text { corpuscles } \\
Z n(\mu g . / m l .)\end{array}$ & $\begin{array}{c}\text { Haematocrit } \\
\text { value }\end{array}$ & $\begin{array}{c}\text { Whole blood } \\
\text { Zn }(\mu \mathrm{g} . / \\
100 \mathrm{ml} .)\end{array}$ & $\begin{array}{c}\text { Urinary } \\
Z n \\
(\mu g . / 24 h r s)\end{array}$ \\
\hline Worker & $\begin{array}{r}1 \\
2 \\
3 \\
4 \\
5 \\
6 \\
7 \\
8 \\
9 \\
10 \\
11 \\
12\end{array}$ & $\begin{array}{l}37 \\
41 \\
33 \\
40 \\
51 \\
30 \\
33 \\
34 \\
27 \\
47 \\
36 \\
41\end{array}$ & $\begin{array}{r}4 \\
18 \\
9 \\
12 \\
21 \\
9 \\
6 \\
5 \\
10 \\
11 \\
17 \\
13\end{array}$ & $\begin{array}{r}96 \\
167 \\
115 \\
90 \\
165 \\
82 \\
76 \\
84 \\
87 \\
83 \\
138 \\
72\end{array}$ & $\begin{array}{r}12.4 \\
16.6 \\
10.8 \\
18.8 \\
18.5 \\
19.6 \\
12.4 \\
14.3 \\
7.2 \\
8.2 \\
16.9 \\
8.9\end{array}$ & $\begin{array}{l}48 \\
50 \\
48 \\
44 \\
46 \\
43 \\
46 \\
47 \\
46 \\
48 \\
50 \\
42\end{array}$ & $\begin{array}{l}645 \\
913 \\
578 \\
878 \\
940 \\
889 \\
611 \\
717 \\
378 \\
437 \\
914 \\
416\end{array}$ & $\begin{array}{l}468 \\
318 \\
363 \\
403 \\
560 \\
408 \\
600 \\
425 \\
382 \\
411 \\
338 \\
385\end{array}$ \\
\hline $\begin{array}{l}\text { Ran } \\
\text { Mea } \\
\text { S.D }\end{array}$ & $\begin{array}{l}\text { nge } \\
\text { an } \pm\end{array}$ & $\begin{array}{l}27-51 \\
37 \cdot 5 \pm 7\end{array}$ & $\begin{array}{r}4-21 \\
11 \pm 5\end{array}$ & $\begin{array}{r}72-167 \\
105 \pm 34\end{array}$ & $\begin{array}{r}7 \cdot 2-19 \cdot 6 \\
14 \pm 4 \cdot 4\end{array}$ & $\begin{array}{c}42-50 \\
46 \cdot 5 \pm 2 \cdot 5\end{array}$ & $\begin{array}{l}378-940 \\
693 \pm 212\end{array}$ & $\begin{array}{l}318-600 \\
422 \pm 84\end{array}$ \\
\hline Subject & $\begin{array}{r}1 \\
2 \\
3 \\
4 \\
5 \\
6 \\
7 \\
8 \\
9 \\
10\end{array}$ & $\begin{array}{l}49 \\
40 \\
28 \\
24 \\
39 \\
41 \\
30 \\
41 \\
27 \\
35\end{array}$ & & $\begin{array}{r}65 \\
110 \\
129 \\
80 \\
96 \\
70 \\
80 \\
76 \\
83 \\
67\end{array}$ & $\begin{array}{r}9.1 \\
10.2 \\
10.0 \\
7.8 \\
9.7 \\
8.0 \\
11.4 \\
10.8 \\
9.5 \\
8.6\end{array}$ & $\begin{array}{l}51 \\
46 \\
37 \\
47 \\
43 \\
44 \\
44 \\
46 \\
44 \\
50\end{array}$ & $\begin{array}{l}496 \\
529 \\
451 \\
409 \\
472 \\
391 \\
546 \\
538 \\
464 \\
463\end{array}$ & $\begin{array}{l}395 \\
340 \\
445 \\
395 \\
338 \\
402 \\
354 \\
387 \\
343 \\
314\end{array}$ \\
\hline $\begin{array}{l}\text { Ran } \\
\text { Mea } \\
\text { S.D. }\end{array}$ & an \pm & $\begin{array}{l}24-49 \\
35 \pm 8\end{array}$ & & $\begin{array}{l}65-129 \\
86 \pm 20\end{array}$ & $\begin{array}{l}7 \cdot 8-11 \cdot 4 \\
9 \cdot 5 \pm 1 \cdot 2\end{array}$ & $\begin{array}{l}37-51 \\
45 \pm 4\end{array}$ & $\begin{array}{l}391-546 \\
476 \pm 52\end{array}$ & $\begin{array}{l}314-445 \\
371 \pm 40\end{array}$ \\
\hline \multicolumn{3}{|c|}{ Comparison of means } & - & $P<0 \cdot 10$ & $P<0.001$ & - & $P<0.001$ & $P<0.05$ \\
\hline
\end{tabular}

zinc content in five subjects in the present study showed close agreement between the measured and calculated values of whole blood zinc, as previously reported by Berfenstam (1952). The haematocrit values in the workers were within the normal range and were not statistically different from those of the control group.

The difference in mean plasma zinc for the two groups was not statistically significant $(P<0 \cdot 10)$, whereas the zinc concentration in the blood corpuscles and in whole blood was raised to a statistically significant level in the workers.

Table 2 presents a comparison of the mean values of urinary zinc, expressed in different ways in the group of exposed workers and in the control group. Division of the 24-hour urinary zinc values by the creatinine content of the 24-hour urine sample gave the urinary zinc concentration per gram creatinine.
TABLE 2

Urinary LeVels of Zinc (Mean Values \pm S.D.) IN 12 Workers WITH CHRONIC EXPOSURE TO ZINC AND 10 CONTROL Non-eXPosed SubJeCts

\begin{tabular}{|c|c|c|c|}
\hline & \multicolumn{2}{|c|}{ Zinc $(\mu g)}$. & \multirow{2}{*}{$\begin{array}{l}\text { Comparison } \\
\text { of means }\end{array}$} \\
\hline & $\begin{array}{l}\text { Workers } \\
(n=12)\end{array}$ & $\begin{array}{l}\text { Control } \\
\text { subjects } \\
(n=10)\end{array}$ & \\
\hline $\begin{array}{l}\text { Quantity excre- } \\
\text { ted in } 24 \mathrm{hrs} \\
\text { Conc. per } \mathrm{g} \text {. } \\
\text { creatinine } \\
\text { Conc. per litre } \\
\text { Conc. per litre } \\
\text { corrected to } \\
\text { density } 1.024\end{array}$ & $\begin{array}{c}422 \pm 84 \\
403 \pm 199 \\
528 \pm 172 \\
593 \cdot 5 \pm 137\end{array}$ & $\begin{array}{c}371 \pm 40 \\
411 \pm 103 \\
436 \cdot 5 \pm 103 \\
496 \pm 121\end{array}$ & 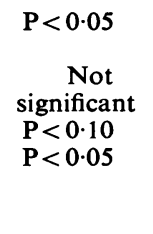 \\
\hline
\end{tabular}


TABLE 3

Zinc in Fasting Gastric Juice and in Gastric Juice Collected $\frac{1}{2}$ hr. and 1 hr. After Gastric Stimulation by Alcohol in 8 Workers With Chronic Exposure to Zinc AND in 7 CONTROL SubJeCts

\begin{tabular}{|c|c|c|c|c|c|c|}
\hline & & \multirow{2}{*}{$\begin{array}{c}\text { Plasma } \mathrm{Zn} \\
(\mu \mathrm{g} . / \\
100 \mathrm{ml} .)\end{array}$} & \multirow{2}{*}{$\begin{array}{l}\text { Zn conc. in } \\
\quad \text { fasting } \\
\text { gastric juice } \\
\text { ( } \mu g . / 100 \mathrm{ml} .)\end{array}$} & \multirow{2}{*}{$\begin{array}{c}\text { Fasting gastric } \\
\text { juice Zn to } \\
\text { plasma Zn } \\
\%\end{array}$} & \multicolumn{2}{|c|}{ Zn conc. in gastric juice } \\
\hline & & & & & $\begin{array}{c}\frac{1}{2} \text { hr. after } \\
\text { alcohol } \\
(\mu g . / 100 \mathrm{ml} .)\end{array}$ & $\begin{array}{c}1 \mathrm{hr} . \text { after } \\
\text { alcohol } \\
(\mu \mathrm{g} . / 100 \mathrm{ml} .)\end{array}$ \\
\hline Worker & $\begin{array}{r}1 \\
2 \\
3 \\
4 \\
6 \\
9 \\
11 \\
12\end{array}$ & $\begin{array}{r}96 \\
167 \\
115 \\
90 \\
82 \\
87 \\
138 \\
72\end{array}$ & $\begin{array}{l}49 \\
32 \\
54 \\
58 \\
79 \\
52 \\
65 \\
36\end{array}$ & $\begin{array}{l}51 \\
19 \\
47 \\
63 \\
96 \\
60 \\
47 \\
50\end{array}$ & $\begin{array}{l}11 \\
46 \\
18 \\
23 \\
47 \\
28 \\
46 \\
36\end{array}$ & $\begin{array}{r}62 \\
125 \\
38 \\
29 \\
56 \\
38 \\
31 \\
25\end{array}$ \\
\hline \multicolumn{2}{|c|}{$\begin{array}{l}\text { Range } \\
\text { Mean } \pm \\
\text { S.D. }\end{array}$} & & $\begin{array}{l}32-79 \\
53 \pm 15\end{array}$ & $\begin{array}{l}19-96 \\
54 \pm 21 \cdot 5\end{array}$ & $\begin{array}{r}11-47 \\
31 \cdot 8 \pm 14\end{array}$ & $\begin{array}{c}25-125 \\
50 \cdot 5 \pm 33\end{array}$ \\
\hline Subject & $\begin{array}{r}1 \\
2 \\
3 \\
4 \\
5 \\
6 \\
10\end{array}$ & $\begin{array}{r}65 \\
110 \\
129 \\
80 \\
96 \\
70 \\
67\end{array}$ & $\begin{array}{l}25 \\
35 \\
50 \\
38 \\
46 \\
37 \\
16\end{array}$ & $\begin{array}{l}38 \\
32 \\
39 \\
47 \cdot 5 \\
48 \\
53 \\
24\end{array}$ & $\begin{array}{l}12 \\
36 \\
22 \\
38 \\
28 \\
27 \\
22\end{array}$ & $\begin{array}{l}18 \\
42 \\
45 \\
24 \\
20 \\
38 \\
18\end{array}$ \\
\hline \multicolumn{2}{|c|}{$\begin{array}{l}\text { Range } \\
\text { Mean } \pm \\
\text { S.D. }\end{array}$} & & $\begin{array}{l}16-50 \\
35 \pm 11 \cdot 7\end{array}$ & $\begin{array}{r}24-53 \\
40 \pm 10\end{array}$ & $\begin{array}{c}12-38 \\
26 \cdot 4 \pm 8 \cdot 9\end{array}$ & $\begin{array}{c}18-45 \\
29 \cdot 2 \pm 11 \cdot 9\end{array}$ \\
\hline
\end{tabular}

TABLE 4

Comparison of Zinc Concentration in Gastric Juice from 8 Workers with Chronic EXPOSURE to Zinc aNd 7 Normal NON-EXPOSEd CONTROL SUBJeCtS

\begin{tabular}{|c|c|c|c|c|c|c|}
\hline & \multicolumn{6}{|c|}{$Z n$ concentration in gastric juice } \\
\hline & \multicolumn{2}{|c|}{$\begin{array}{c}\text { Fasting } \\
(\mu g . / 100 \mathrm{ml} .)\end{array}$} & \multicolumn{2}{|c|}{$\begin{array}{l}\frac{1}{2} \text { hr. after alcohol } \\
(\mu g . / 100 \mathrm{ml} .)\end{array}$} & \multicolumn{2}{|c|}{$\begin{array}{c}1 \mathrm{hr} . \text { after alcohol } \\
(\mu \mathrm{g} .1100 \mathrm{ml} .)\end{array}$} \\
\hline & Mean \pm S.D. & S.E.M. & Mean $\pm S . D$. & S.E.M. & Mean \pm S.D. & S.E.M. \\
\hline Workers & $53 \pm 15$ & $5 \cdot 3$ & $31 \cdot 8 \pm 14$ & $4 \cdot 9$ & $50 \cdot 5 \pm 33$ & $11 \cdot 3$ \\
\hline Control subjects & $35 \pm 11 \cdot 7$ & $4 \cdot 4$ & $26.4 \pm 8.9$ & $3 \cdot 35$ & $29 \cdot 2 \pm 11 \cdot 9$ & $4 \cdot 5$ \\
\hline Comparison of means & $P<0.02$ & & Not significant & & $P<0 \cdot 10$ & \\
\hline
\end{tabular}

Multiplication of the zinc values per litre by 0.024 $\frac{024}{(\mathrm{D}-1 \cdot 0)}$, where $\mathrm{D}$ was the urine density at room temperature, yielded density-corrected zinc values (Levine and Fahy, 1945).

Zinc concentration in gastric secretion

Table 3 shows the results of zinc determination in the fasting gastric juice and in gastric juice collected half an hour and one hour after alcohol intake in eight furnace operators and seven control subjects. Percentages of fasting gastric juice zinc to plasma zinc are also given. In Table 4 and in Fig. 1 are compared the mean zinc concentrations in the gastric juice of both groups.

The mean zinc concentration in fasting gastric juice was statistically higher $(P<0.02)$ in the workers 


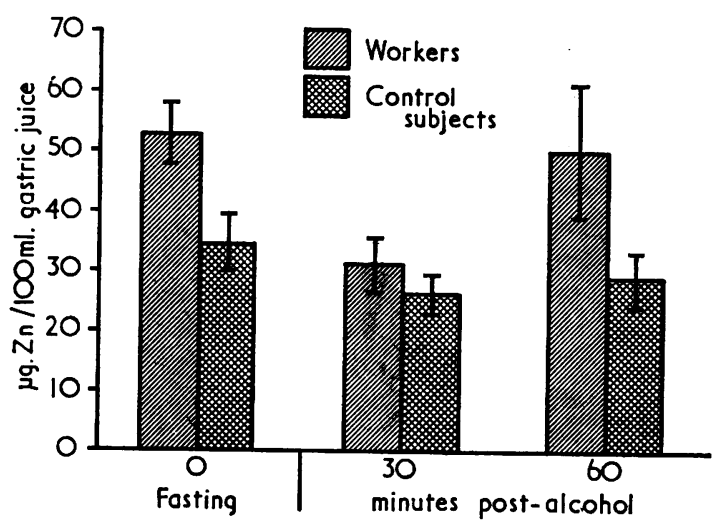

FIG. 1. Mean zinc concentration in gastric secretion from eight workers with chronic exposure to zinc and from seven control subjects. Vertical line at top of each bar represents \pm 1 standard error.

than in the normal control subjects. The difference in mean percentage of the fasting gastric juice zinc to plasma zinc for the workers and the control subjects was not significant $(P<0 \cdot 10)$; but there was a much wider individual spread of these percentages in the workers than in the normal subjects. In worker no. 6 , the zinc concentration in the fasting gastric juice was almost the same as in the plasma (Table 3).

Half an hour and one hour after alcohol intake, there was a relatively higher mean zinc concentration in the gastric juice of the workers than of the control subjects, more so at one hour, but the difference in mean zinc concentrations for the two groups was not statistically significant at either interval.

After stimulation of the stomach by alcohol, the zinc concentration in the gastric juice was found to follow, in general, the same pattern in both the control subjects and the workers. In both groups, the mean levels of zinc in the gastric secretion showed a tendency to diminish half an hour after stomach stimulation and to increase again one hour after stimulation. The magnitude of depression from the fasting level to the half-hour post-stimulation level in the workers was statistically significant $(P<0.01)$ whereas the depression in the control group was not significant $(P<0 \cdot 10)$. One hour after stimulation, there was no statistically significant difference between the mean zinc concentration in the gastric secretion and that in the fasting gastric juice in either group.

Table 5 shows the average degrees of free $\mathrm{HCl}$ and total acidity in the fasting gastric juice of the workers and of the control subjects and in the gastric secretion collected every 15 minutes after stomach stimulation by alcohol for two hours in the workers and for one and a half hours in the normal control subjects. Curves of the average free $\mathrm{HCl}$

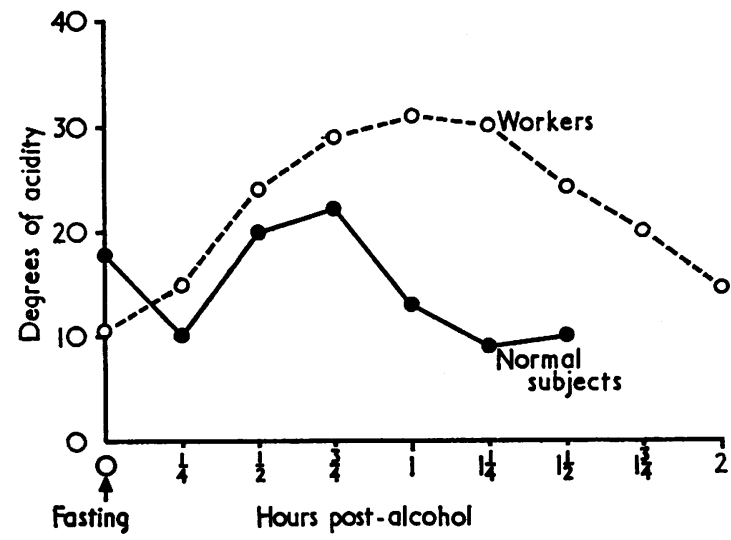

FIG. 2. Average gastric juice acidity (free $\mathbf{H C l}$ ) in eight workers (furnace operators in a brass foundry) and seven normal control subjects.

Average volume of fasting gastric juice: workers, $41 \mathrm{ml}$.; control subjects, $37 \mathrm{ml}$.

TABLE 5

Average Degrees of Free hC1 and Total Acidity in Gastric Juice of 8 Furnace Operators IN A Brass FoundRY aNd 7 NORMal CONTROL SUbJects

\begin{tabular}{|c|c|c|c|c|c|c|c|c|c|}
\hline & \multirow{2}{*}{ Fasting } & \multicolumn{8}{|c|}{ Hours post-alcohol } \\
\hline & & 1 & $\frac{1}{2}$ & $\frac{1}{4}$ & 1 & 11 & $1 \frac{1}{2}$ & $1 \frac{1}{4}$ & 2 \\
\hline $\begin{array}{l}\text { Workers (8) } \\
\text { Free HCl } \\
\text { Total acidity }\end{array}$ & $\begin{array}{l}10 \cdot 8 \\
26 \cdot 6\end{array}$ & $\begin{array}{l}15.2 \\
23.0\end{array}$ & $\begin{array}{l}23.7 \\
33.5\end{array}$ & $\begin{array}{l}29.0 \\
39 \cdot 7\end{array}$ & $\begin{array}{l}30.3 \\
41.5\end{array}$ & $\begin{array}{l}29 \cdot 7 \\
39 \cdot 2\end{array}$ & $\begin{array}{l}24.6 \\
35.5\end{array}$ & $\begin{array}{l}20.7 \\
31.8\end{array}$ & $\begin{array}{l}14.3 \\
31.8\end{array}$ \\
\hline $\begin{array}{l}\text { Control subjects (7) } \\
\text { Free HC1 } \\
\text { Total acidity }\end{array}$ & $\begin{array}{l}17.8 \\
35.8\end{array}$ & $\begin{array}{l}10 \cdot 1 \\
21 \cdot 4\end{array}$ & $\begin{array}{l}20 \cdot 7 \\
35 \cdot 1\end{array}$ & $\begin{array}{l}22 \cdot 4 \\
36 \cdot 5\end{array}$ & $\begin{array}{l}13.2 \\
27.7\end{array}$ & $\begin{array}{r}9.0 \\
23.0\end{array}$ & $\begin{array}{l}10 \cdot 0 \\
23.0\end{array}$ & & \\
\hline
\end{tabular}


values in both groups are presented in Figure 2. The maximum degrees of acidity reached in the workers were within the normal acidity range, but the acidity curves showed that the decline in acidity started about half an hour later in the workers than in the normal subjects and took a longer time to be complete.

\section{Discussion}

The mean plasma zinc concentration for the normal control subjects in the present study $(86 \pm 20 \mu \mathrm{g}$. $\mathrm{Zn} / 100 \mathrm{ml}$.) was significantly less than the mean plasma or serum zinc concentration for normal subjects found by other investigators (Berfenstam, 1952; Helwig et al., 1966). Plasma and serum zinc levels have been found to be the same for the same subject (Berfenstam, 1952). The mean normal plasma zinc level in the present series was also lower than that of $102 \pm 13 \mu \mathrm{g} . / 100 \mathrm{ml}$. and $108 \pm 8 \mu \mathrm{g} . / 100 \mathrm{ml}$. reported by Prasad and his colleagues (1963a, b) in 19 and nine normal Egyptians respectively. Our lower plasma zinc levels may be ascribed to a difference in the method of zinc determination. In the present study, acid digestion of samples was performed but Prasad and his colleagues extracted zinc with hydrochloric acid and precipitated the protein with trichloroacetic acid. Berfenstam (1952) obtained higher zinc values by extraction with acid than by ashing. But our mean normal plasma zinc value was statistically in accord with the mean normal serum zinc value of $91 \pm 16.7 \mu \mathrm{g} . / 100 \mathrm{ml}$. reported by Helwig and his colleagues (1966) among 64 control subjects; it was the wet ashing technique of Helwig that was used in our study.

Although the mean plasma zinc concentration in the workers tended to be higher than normal it was not raised to a statistically significant level (Table 1). However, the workers had a significantly higher mean concentration of zinc in the blood corpuscles than did the normal non-exposed subjects. The mean zinc concentration in whole blood was also significantly higher in the workers, which is understandable since erythrocytes account for about $85 \%$ of whole blood zinc, leucocytes for $3 \%$, and serum for about $12 \%$ (Vallee, 1962).

Chronic exposure to zinc therefore resulted in the accumulation of zinc in the blood corpuscles while the plasma zinc was not significantly increased. It should be noted that the exposure to zinc of the group of furnace operators investigated was not a typically chronic exposure over the eight-hour shift; it was a chronic exposure to zinc oxide fumes with repeated acute exposures every day to very high concentrations. It is possible to explain why the plasma zinc level was not significantly increased in these workers on the assumption that, on chronic exposure to zinc of the nature described, there occurs an increase of zinc in the plasma which is rapidly excreted via various channels. Blood corpuscles, on the other hand, act as a storage depot for the increased body burden of zinc, and hence their zinc content is significantly increased. The findings of zinc metabolism studies in animals (Montgomery, Sheline, and Chaikoff, 1943; Sheline, Chaikoff, Jones, and Montgomery, 1943a, b; Berfenstam, 1952) as well as in man (Graig and Siegel, 1960) lend support to our findings of rapid elimination of zinc from the plasma and its accumulation in the blood corpuscles of exposed workers. This raises the question whether the increased corpuscular zinc in these workers might influence the activity of their carbonic anhydrase, zinc being an essential component of the enzyme present in red blood cells.

The mean 24-hour urinary excretion of zinc in the normal subjects in the present study was comparable with the findings of Sullivan and Lankford (1962), who reported an excretion of $402 \pm 150 \mu \mathrm{g} . \mathrm{Zn}$ per day in 22 normal individuals. It was a little higher than the average normal daily urinary zinc excretion of $0.3 \mathrm{mg} . \mathrm{Zn}$ per day found by McCance and Widdowson (1942), and lower than the mean normal values given by other investigators (Helwig et al., 1966). It was also lower than the mean value reported by Prasad et al. (1963b) in normal Egyptians. Vallee, Wacker, Bartholomay, and Hoch (1957) found a mean normal excretion of $440 \mu \mathrm{g}$. of zinc per litre of urine with a standard deviation of $210 \mu \mathrm{g}$. This value compares with our present finding (Table 2).

Complete collection of urine was checked by creatinine determination in the 24-hour samples. The variations in creatinine excretion in the workers investigated were within the range of expected normal variation given by Bleiler and Schedl (1962). The use of creatinine excretion as a reference in interpreting the excretion of other metabolites may, however, be invalid when based on single urinary creatinines, which was the case in the present study in which creatinine was calculated in single 24-hour specimens. Moreover, the concentration of a substance per litre of urine adjusted to specific gravity of 1.024 has been suggested as a better index of exposure than timed samples (Elkins and Pagnotto, 1965). In the present study, the urinary zinc concentration per gram of creatinine was not statistically different in the workers and the control subjects, whereas both the mean 24-hour urinary zinc excretion and the mean urinary zinc concentration per litre corrected to a density of 1.024 were found to be higher in the workers exposed to zinc than in the control group, the difference between the two groups having a low order of significance $(P<0.05$, Table 2$)$. It can, therefore, safely be stated that urinary zinc excretion was slightly higher in the exposed workers than in normal non-exposed subjects. 
Zinc excretion in the gastro-intestinal tract was investigated, in the present study, only in terms of zinc concentration in the gastric secretion. Despite extensive studies on zinc metabolism, information on the role of the stomach as a possible organ of zinc excretion is not available either in animals or in man. Zinc excretion through other gastro-intestinal organs has been studied by many investigators (Montgomery et al., 1943; Sheline et al., 1943a; Mager, McNary, and Lionetti, 1953; Birnstingl, Stone, and Richards, 1956; Rubini, Montalvo, Lockhart, and Johnson, 1961; Sullivan, O'Grady, and Lankford, 1965). Our findings do not allow definite conclusions concerning gastric zinc secretion either in normal subjects or in industrial workers with chronic exposure to zinc. However, they show that zinc was present in the secretions obtained by gastric aspiration in the normal subjects. They also demonstrate that it was present in a significantly higher concentration in the fasting gastric juice of the exposed workers than in that of the normal control subjects.

There is no information in the literature on the zinc content of gastric secretion after stimulation of the stomach to provide a statistically meaningful range of zinc in the human gastric secretion. In the present study, stimulation of the stomach by alcohol resulted in predictable changes in zinc concentration during the post-stimulation period in both the normal subjects and the exposed workers. Gastric stimulation is known to increase the volume of gastric secretion and this could account for the diminished zinc concentration in the gastric secretion half an hour after stimulation. The increase in gastric juice zinc concentration half an hour after stimulation in worker no. 2 and in control subject no. 10 (Table 3 ) could presumably be explained by increased excretion of zinc in the gastric juice at this interval in the presence of an expected increase in the volume of gastric secretion. Individual zinc concentrations in the gastric secretion one hour after stimulation were either diminished or increased compared with the half-hour levels both in the normal subjects and in the workers. This was probably due to the rate of gastric secretion after stomach stimulation which is expected to show individual variation. One hour after gastric stimulation, worker no. 2 still showed an abnormally high gastric juice zinc concentration which implies an abnormally high zinc excretion after stomach stimulation in this worker rather than a reduced volume of gastric secretion.

Compared with normal control subjects, the workers with chronic exposure to zinc were found to have a significantly higher mean zinc concentration in the fasting gastric juice and a relatively higher mean zinc concentration in the half-hour and onehour post-stimulation gastric secretion. This finding could be due to turnover of zinc by the stomach from an increased load in the worker's plasma, the metal being eliminated partially via the gastric secretion, or to active secretion of zinc from the gastric mucosa, gastric tissue having acquired a higher zinc uptake in the exposed workers than in the non-exposed control subjects, or it may be due partly to increased ingestion of zinc from the contaminated hands of workers; or it could be due to more than one of these factors.

Gastric juice could have been contaminated by saliva despite the precautions taken to avoid such contamination. Although regurgitating bile or duodenal juice might have contaminated the gastric juice samples bile was not detected in any of them.

Because the total volume of gastric secretion was not measured in the post-alcohol stimulation period, and the zinc output or total zinc content of gastric secretion after stomach stimulation was not estimated our present findings cannot elucidate the magnitude of difference in zinc excretion through the stomach between the workers with chronic exposure to zinc and the normal non-exposed individuals. But the difference in mean gastric juice zinc concentrations between the two groups could suggest that, on chronic exposure to zinc oxide fumes in industry, the zinc concentration in gastric secretion is increased, gastric secretion having been found in the present study to be a normal excretory pathway of zinc in man. This increase in zinc concentration could account, at least in part, for the gastric complaints present in 10 out of the 12 workers investigated, zinc chloride being known to be highly irritant to the stomach mucosa. The gastric complaints, manifested mainly as epigastric pain after food intake, could also be due to the presence of other atmospheric contaminants such as the other metals used in the manufacture of the alloys, or to the type of gastric acidity curve of the workers (Fig. 2). The latter would probably potentiate the effect of increased zinc concentration in the gastric secretion of the workers.

Thanks are due to Dr. S. Soliman, Department of Analytical Chemistry, Faculty of Pharmacy, Alexandria University, for his help in the development of the zinc analysis technique.

\section{References}

Batchelor, R. P., Fehnel, J. W., Thomson, R. M., and Drinker, K. R. (1926). A clinical and laboratory investigation of effect of metallic zinc, of zinc oxide, and of zinc sulphide upon the health of workmen. J. industr. Hyg., 8, 322-363.

Berfenstam, R. (1952). Studies on blood zinc. Acta paediat. (Uppsala), 41, Suppl. 87, pp. 3-97.

Birnstingl, M., Stone, B., and Richards, V. (1956). Excretion of radioactive zinc $\left(\mathrm{Zn}^{65}\right)$ in bile, pancreatic and duodenal secretions of the dog. Amer J. Physiol., 186, 377-379.

Bleiler, R. E., and Schedl, H. P. (1962). Creatinine excretion: Variability and relationships to diet and body size. J. Lab. clin. Med., $59,945-955$. 
Drinker, P. (1922). Certain aspects of the problem of zinc toxicity. J. industr. Hyg., 4, 177-197.

du Bray, E. S. (1937). Chronic zinc intoxication. J. Amer. med. Ass., 108, 383-385.

Elkins, H. B., and Pagnotto, L. D. (1965). Is the 24-hour urine sample a fallacy? Amer. industr. Hyg. Ass. J., 26, 456-460.

Evans, E. H. (1945). Casualties following exposure to zinc chloride smoke. Lancet, 2, 368-370.

Graig, F. A., and Siegel, E. (1960). Distribution in blood and excretion of $\mathrm{Zn}^{65}$ in man. Proc. Soc. exp. Biol. (N.Y.), 104, 391-394.

Helwig, H. L., Hoffer, E. M., Thielen, W. C., Alcocer, A. E., Hotelling, D. R., and Rogers, W. H.(1966). Modified zinc analysis method and serum and urinary zinc levels in control subjects. Amer. J. clin. Path., 45, 160-165.

Kägi, J. H. R., and Vallee, B. L. (1958). Determination of zinc by direct extraction from urine with diphenylthiocarbazone. Analyt. Chem. (Wash.), 30, 1951-1954.

Levine, L., and Fahy, J. P. (1945). Evaluation of urinary lead determinations. I. The significance of the specific gravity. J. industr. Hyg., 27, 217-223.

Mager, M., McNary, W. F., Jr., and Lionetti, F. (1953). The histochemical detection of zinc. J. Histochem. Cytochem., 1, 493-504.

Malmström, B. G. (1956). Determination of zinc in biological materials. In Glick, D., editor: Methods of Biochemical Analysis, Vol. 3, pp. 327-352. Interscience Publishers, New York.

McCance, R. A., and Widdowson, E. M. (1942). The absorption and excretion of zinc. Biochem. J., 36, 692-696.

McCord, C. P., Friedlander, A., Brown, W. E., and Minster, D. K. (1926). An occupational disease among zinc workers. Arch. intern. Med., 37, 641-65s.

Montgomery, M. L., Sheline, G. E., and Chaikoff, I. L. (1943). The elimination of administered zinc in pancreatic juice, duodenal juice, and bile of the $\operatorname{dog}$ as measured by its radio-active isotope $\left(\mathrm{Zn}^{65}\right)$. J. exp. Med., 78, 151-159.

Noro, L., and Uotila, U. (1954). Paper 239, XI int. Congr. industr. Med., Naples, Sept. 1954, p. 116.
Prasad, A. S., Miale, A., Farid, Z., Sandstead, H. H., and Schulert, A. R. (1963a). Zinc metabolism in patients with the syndrome of iron deficiency anemia, hepato-splenomegaly, dwarfism, and hypogonadism. J. Lab. clin. Med., 61, 537-549.

, Sandstead, H. H., Schulert, A. R., and El Rooby, A. S. (1963b). Urinary excretion of zinc in patients with the syndrome of anemia, hepatosplenomegaly, dwarfism and hypogonadism. Ibid., 62 , 591-599.

Rubini, M. E., Montalvo, G., Lockhart, C. P. and Johnson, C. R. (1961). Metabolism of zinc-65. Amer. J. Physiol., 200, 1345-1348.

Sheline, G. E., Chaikoff, I. L., Jones, H. B., and Montgomery, M. L. (1943a). Studies on the metabolism of zinc with the aid of its radioactive isotope. II. The distribution of administered radioactive zinc in the tissues of mice and dogs. J. biol. Chem., 149, 139.

- - (1943b). Studies on the metabolism of zinc with the aid of its radioactive isotope. I. The excretion of administered zinc in urine and feces. Ibid., 147, 409.

Sullivan, J. F., and Lankford, H. G. (1962). Urinary excretion of zinc in alcoholism and postalcoholic cirrhosis. Amer. J. clin. Nutr., 10, 153-157.

-, O'Grady, J., and Lankford, H. G. (1965). The zinc content of pancreatic secretion. Gastroenterology, 48, 438-443.

Uotila, U., and Noro, L. (1957). Folia med. (Napoli), 40, 245.

Vallee, B. L. (1962). Zinc, Ed. Comar, C. L., and Bronner, F., In Mineral Metabolism, vol. 2, Part B, pp. 443-482. Academic Press, New York and London.

, Wacker, W. E. C., Bartholomay, A. F., and Hoch, F. L. (1957). Zinc metabolism in hepatic dysfunction. II. Correlation of metabolic patterns with biochemical findings. New Engl. J. Med., 257, 1055-1065.

,,---1 (1959). Zinc metabolism in hepatic dysfunction. Ann. intern. Med., 50, 1077-1091.

Wootton, I. D. P. (1964). Micro-analysis in Medical Biochemistry (originally written by E. J. King), 4th ed. p. 174. Churchill, London.

Received for publication July 2, 1968. 